\title{
Mobbing in a Workplace and Its Negative Influence on Building Quality Culture
}

\author{
Martina Minárová ${ }^{1, *}$, Dana Benčiková2 $^{2}$ Denisa Malá $^{1}$, and Filip Smutný ${ }^{1}$ \\ ${ }^{1}$ EF UMB in Banská Bystrica, Department of Corporate Economics and Management, 97590 Banská \\ Bystrica, Slovakia \\ ${ }^{2} \mathrm{EF}$ UMB in Banská Bystrica, Department of Language Communication in Business, 97590 Banská \\ Bystrica, Slovakia
}

\begin{abstract}
Globalization is one of the most significant trends of the contemporary reality that needs to be accepted and adapted to the changes it brings. Human resources have always been viewed by enterprises as a significant long-term functioning capital. Along with new creative work skills, HR currently represent one of the most crucial potentials within an enterprise, enabling it to achieve competitive advantage among rivals. Thus HR serve as a source of the future success of an enterprise. People spend a substantial amount of time at work, and satisfactory working conditions are essential for their psychological well-being, as they can greatly affect both the person's work performance and the overall quality of life. In order for an enterprise to fulfill the criteria of the contemporary globalized world, management needs to adhere to this trend not only by adjusting the organizational structure, but also by maintaining more complex interpersonal relations among employees. It is the relations that may create conditions for mobbing or psychological bullying to occur, while originating from one or more members of a team, and being directed towards other individuals. In this paper, the authors present selected results of a research related to mobbing in Slovakia, which investigated the degree of its occurrence in a workplace, its most frequent causes, and the manifestations of negative behavior. In conclusion, we propose such measures that will prevent any form of violent behavior from occurring in the workplace, and will have a positive impact on building culture of quality in an enterprise.
\end{abstract}

\section{Introduction}

Globalization and the increasing pressure of competition have created a new dimension for the competitive environment that requires a radical turn in the thinking of each company employee. These days, it is not sufficient to build business success merely by providing quality products. Increasingly, business prosperity depends on established values and standards, rules, behavioral patterns and rituals, based on corporate culture [1]. If the management of an enterprise can draw attention to company employees, it can positively

\footnotetext{
*Corresponding author: martina.minarova@umb.sk
} 
affect the quality of work, efficiency of employees, and ultimately, it has high impact on the total business performance. Only those enterprises that possess a strong corporate culture and are oriented on internal coherence and mutual achievement of goals, will gain a competitive advantage which can significantly distinguish them from other enterprises [2].

Every culture is strong if it is desirable, if employees understand it, and especially if the management of an enterprise lives it on a daily basis. The key to success of a positive corporate culture is the behavior of the enterprises's management, as well as effective mutual communication. Behavior of the management must be perceived as coherence between what they want, or what they declare, and how they actually act [3] In recent years, the global workplace has been changing significantly, and this change often leads to clash of cultures. The processes of globalization of today's world lead to adopting both positive and negative tactics of fight for survival, which are referred to as psychoterror in the workplace. This includes oppression, mobbing, physical violence, and/or sexual harassment, which have a negative impact on building culture of quality in an enterprise. Culture of quality should be viewed as organizational culture that contains basic assumptions, values, standards of behavior and attitudes that lead employees to achieving truly high quality $[4,5,6]$. The authors identify this content of quality culture as ideal. In defining the ideal content of culture of quality, many authors rely on the model of corporate culture by [7].

As suggested above, the content of culture of quality is defined at the level of basic assumptions and organizational values. At the level of basic assumptions, an ideal content of culture of quality was defined by [8]. According to [8], basic assumptions that make the content of culture of quality are the following: quality is key to customer satisfaction, as well as to achieving long-term profitability of an organization; an organization is able to achieve quality; low quality may destroy performance of the organization, interests of customers, and even employees of the enterprise. Quality concerns stakeholders in an enterprise. One of the factors that can disrupt the culture of quality in an enterprise is the workplace, in case it supports the occurrance of mobbing. Regarding mobbing, it is neccessary to mention that quality of working life directly influences the quality of personal life. Mobbing refers to repeated verbal, physical or mental pressure and attacks against an individual in a working team. These attacks focus on hurting, humiliating, or destroying the individual in question, as well as haring their good reputation, making their working conditions unpleasant, and sabotage their work to such extent that the sabotaged individual cannot deliver full performance that is required of them [9].

Mobbing is perceived as a society-wide problem that we can face in all work-related areas, which has been pointed out by several scholars. Mobbing predictors, its reasons, behavior, the advantages of identifying its first symptoms, its impact on the victim of violence, on the organization and the whole society, as well as possible solutions, these are all subject of research of several authors [10, 11, 12, 13, 14]. When generalizing the knowledge in this area, the definition of mobbing may include: long-term attacks directed towards one person, malicious and demeaning violence, gossiping and mockery with a defined goal - to isolate a person separate them from a team/group. It is an effort to force a person to leave the workplace, to eliminate the collaboration of others with the bullied person, or to restrict social relations between other people with this individual. The mentioned expressions of bullying behavior would be seen occurring in a longer time, at least half a year, and at least once a week [15]. In addition, mobbing in the workplace causes serious problems in a society and also in the enterprise in question, but especially in the life of the victim of mobbing behavior. The destructive spiral effect of mobbing, as reported by [16], has serious consequences not only for the victims, but also for their families, their community, the enterprise or organization they work in, and also for the entire society. According to a Swedish research, as many as 10-20\% of all suicides may be 
related to mobbing. In Norway, 100 mobbing victims commit suicide every year, in Sweden, every six suicide is claimed to be related to this issue [17]. According to [16] the main effect of mobbing, which appeared to be most interfering with the victims' lives was the disruption of the quality of their life, as well as their career status (43.5\%), followed by more difficult self-enforcement (33\%). Other unpleasant effects of mobbing were attacks on social relations $(16.3 \%)$, lowered self-respect $(6.2 \%)$, and harming the victim's health (1.0\%). A survey (2011) by the international work server Monster, which was performed among the site's visitors, revealed that it is the Europeans who have the most frequent experience with bullying (up to $83 \%$ in the past, compared to $65 \%$ of Americans and $55 \%$ of Asians).

To avoid bullying behavior in the workplace, it is important to focus primarily on prevention. The main burden of prevention should be borne by the employer, who should be the one creating a friendly and peaceful atmosphere, in which the risk of bullying is reduced. The first step is to build such corporate culture that is based on good quality moral foundations. The issue of mobbing, and the efforts to identify and eliminate this problem require the involvement of different experts, and a multidisciplinary approach that involves its clear definition at the medical level. At the same time, it is essential to adopt proper legal regulations, as well as efficient preventive measures. With regard to this, it is highly viable to create preventive programs in workplaces, which is best to be done in collaboration with psychologists, to provide trainings for employees, especially the ones focused on developing social and emotional intelligence, tolerance and effective solutions of conflicts in the workplace, and finaly to motivate employees to positively change their relationships. Courses training assertive behavior also seem as a very effective choice. Only a healthy working atmosphere creates suitable conditions for teamwork and employee satisfaction. Investment in this field is a great advantage not only for the individuals but also for the whole organization [12].

\section{Survey methodology}

The subject of a survey performed within the scientific project VEGA 1/0318/19 at Faculty of Economics at Matej Bel University was to find out about the situation in a workplace of Slovak enterprises, i.e. to what extent mobbing is occurring, what the consequences and impacts on the victim of mobbing are, and also how the overall working atmosphere and other employees are affected. In the survey, we used an empirical method via an online questionnaire. We obtained responses from 156 respondents from private and public organizations and enterprises. The questionnaire consisted of 26 items, while within the statistical analysis of the questions and testing of statistical hypotheses, we used the statistical program Excel and Statistics. To evaluate the date, the methods of mean was used, while the responses to individual questions and the overall results are presented in tables and graphs. In testing the hypotheses, we used the Student's t-test and One-Factor Analysis of Variance at a significance level of 0.05 . The aim of the survey was to determine to what extent mobbing occurs in our workplaces, what types of negative behavior victims of mobbing are facing most frequently. We were also interested in how this individual perceives the experience and what impacts and consequences it brings to them, as well as how the victim defends themselves against further bullying. Other areas of interest included identification of who the mobber is in most cases, whether employees have enough knowledge related to mobbing in the workplace, and whether they know where they can turn if mobbing occurs in their workplace. Based on the theoretical knowledge and the cited empirical studies related to the issue, we formulated several hypotheses. 


\section{Results and discussion}

156 respondents took part in our questionnaire survey, while 92 were women (representing $58.97 \%$ ) and 64 men (41.03\%). Respondents were divided into different age categories, whith the largest group being respondents between 20-29 (99 respondents, i.e. 63.46\%), and the the smallest group 60 years of age and higher. As to their achieved education level, the largest number of respondents have achieved university level of education (75 respondents $-48.07 \%$ ), with least respondents being of secondary education without the final certifical $(29-18.59 \%)$. With regard to their working position, the majority of respondents were regular employees $-137(88 \%)$, while the remaining $19(12 \%)$ worked at managerial positions. We were also interested in how long the respondents have been employed by the enterprise, as it often affects the behavior of employees and superiors. The survey showed that 39 employees $(25 \%)$ had a short working experience in the enterprise, i.e. less than 1 year, 37 employees $(23.7 \%)$ were in the range of 1-2 years of work experience, 34 employees $(21.8 \%)$ in the range of $3-5$ years, 15 employees $(9.6 \%)$ of $6-10$ years, and the remaining 31 employees (19.9\%) have been working in their enterprise for more 10 years. The last question related to socio-demographic data asked about the type of enterprise which respondents work in. $68 \%$ of our respondents work in the private sector, and $32 \%$ in state-owned enterprises. More than half of the respondents (53\%) confirmed that they have experienced mobbing in the workplace, while 73 of them were the victims. In most cases, the mobber was a superior person (85.6\%), which suggests that mobbing has taken the form of bossing. The results also showed that mobbing occurs in both private and state-owned enterprises. The victims of mobbing were mainly younger employees with lower education and more men than women (similar results were published in 2008 by GFK agency or JOB 3000 agency, where $80 \%$ of respondents were victims of mobbing).

Table 1 shows what forms of negative behavior employees were facing in their workplace, and how often it happened. Most often, respondents faced criticism of their work, various insults, humiliation, mockery, and pressure. Excessive control, excessive workload or even ignoring the victim of mobbing proved to be less common. Occasionally, the respondents confirmed the lack of work acknowledgment, or even sexual harassment in workplaces.

Table 1. Types of negative behavior in the workplace.

\begin{tabular}{|c|c|c|c|c|}
\hline Variable & Valid N & Average & Median & Standard deviation \\
\hline Humiliation and mockery & 73 & 3.5890 & 3.0000 & 1.631594 \\
\hline Excessive workload & 73 & 2.9726 & 3.0000 & 0.999619 \\
\hline Excessive control & 73 & 2.8219 & 3.0000 & 0.887294 \\
\hline Underestimated work & 73 & 2.3151 & 2.0000 & 0.664093 \\
\hline Excessive tasks & 73 & 2.4247 & 2.0000 & 1.053009 \\
\hline Ignoring & 73 & 3.5890 & 2.0000 & 1.832088 \\
\hline Gossiping & 73 & 2.5068 & 2.0000 & 1.001711 \\
\hline Insults & 73 & 3.2055 & 4.0000 & 1.189758 \\
\hline Sexual harassment & 73 & 2.0274 & 2.0000 & 0.164368 \\
\hline Pressure & 73 & 3.3151 & 2.0000 & 1.413002 \\
\hline Criticism of work & 73 & 3.7260 & 4.0000 & 1.574628 \\
\hline
\end{tabular}


Our respondents have a tendency to view the solution to mobbing problems by attempting to solve them on their own, most often by talking the problem through with their supervisor or the mobber, while $63 \%$ of the employees who were mobbed considered leaving the job (16.4\%). Two respondents $(2.7 \%)$ would use legal services to protect themselves, and 12 employees $(17.9 \%)$ claimed to be undecided about what to do and how to handle the situation, mostly because they are afraid to lose their jobs by pointing out bullying in their workplace. Workplace is a place where employees spend most of their time and it is very important for them to feel comfortable there, as their work performance highly depends on this. The time when the first symptoms of mobbing appear is individual, and depends on many factors. The most common consequences of mobbing may often be psychological, often resulting in mental problems, such as anxiety, restlessness, failure to concentrate, while they may be associated with self-esteem issues, doubting oneself, or may lower the individual's self confidence. Along with this, quality of work is dramatically reduced as a result of lower self-confidence, which has also been confirmed by the results of our survey. 67 victims (92\%) of mobbing admitted that this unpleasant situation in the workplace had a negative impact on the quality of their work (increased error rate in administrative work and production, passive approach to work, and avoiding to work in a team).

The results of the survey also prove that there appears to be no individual in Slovak enterprises who would be competent to deal with mobbing-related conflicts and situations, or they seem not to possess the knowledge of what to do. Another negative finding was the lack of administrative tools in many companies to define what mobbing and bossing are, and how to deal with conflicts, as it was reported by 125 of our respondents. More than half of respondents $(52 \%)$ do not consider it important to address this pathological phenomenon in front of their superiors, as they do not believe it would help solve the given issues. Only $15 \%$ of respondents trust their superiors, which is a very alarming fact, because trust should be the foundation for developing good working relationships and for building a strong corporate culture and culture of quality.

\section{Evaluation of hypotheses}

$\mathbf{H}_{0}$ : We assume there is no statistical correlation between the occurrence of mobbing in the workplace and the type of organization in which the mobbed person is working.

$\mathbf{H}_{1}$ : We assume that mobbing occurs more often in state-owned companies or organizations than in private ones.

From the results of the Student t-test (at the significance level of 0.05 ), we may conclude a statistically significant difference between the occurrence of mobbing in the workplace and the type of organization ( $\mathrm{p}$-value $=0.04988<0.05$ ). The results are surprising, mainly because the occurrence of mobbing in the sample of respondents was higher in state organizations than in the private ones. Thus we confirm hypothesis $\mathbf{H}_{\mathbf{1}}$. 
Table 2. Type of organization / Occurrence of mobbing in the workplace.

\begin{tabular}{|c|c|c|c|c|c|c|c|c|}
\hline \multicolumn{9}{|c|}{ Pivot table Type of organization/ Occurrence of mobbing in the workplace } \\
\hline $\begin{array}{c}\text { Type of } \\
\text { organization }\end{array}$ & \multicolumn{3}{|c|}{$\begin{array}{c}\text { Mobbing in the workplace } \\
\text { YES }\end{array}$} & \multicolumn{3}{|c|}{$\begin{array}{l}\text { Mobbing in the } \\
\text { workplace } \\
\text { NO }\end{array}$} & \multicolumn{2}{|c|}{ Total lines } \\
\hline private & \multicolumn{3}{|c|}{50} & \multicolumn{3}{|c|}{56} & \multicolumn{2}{|c|}{106} \\
\hline state-owned & \multicolumn{3}{|c|}{32} & \multicolumn{3}{|c|}{18} & \multicolumn{2}{|c|}{50} \\
\hline Sum & \multicolumn{3}{|c|}{82} & \multicolumn{3}{|c|}{74} & \multicolumn{2}{|c|}{156} \\
\hline & \multicolumn{8}{|c|}{$\begin{array}{l}\mathrm{t} \text { tests, grouped: Type of organization } \\
\text { Group 1: private } \\
\text { Group 2: state-owned }\end{array}$} \\
\hline Variable & $\mathrm{t}$ & sv & $\mathrm{p}$ & $\begin{array}{c}\mathrm{N} \\
\text { private }\end{array}$ & $\begin{array}{c}\mathrm{N} \\
\text { state }\end{array}$ & $\begin{array}{c}\text { standard } \\
\text { deviation } \\
\text { private }\end{array}$ & $\begin{array}{l}\text { standard } \\
\text { deviation } \\
\text { state } \\
\text { owned }\end{array}$ & $\begin{array}{c}\mathrm{F} \\
\text { ratio }\end{array}$ \\
\hline $\begin{array}{l}\text { Mobbing in } \\
\text { the } \\
\text { workplace }\end{array}$ & 1.976534 & 154 & 0.049880 & 106 & 50 & 0.501570 & 0.484873 & 1.070056 \\
\hline
\end{tabular}

H2: We assume that there is no statistical dependence between gender (age and education respectively) and the occurrence of mobbing.

H3: We assume that men are more bullied than women in the workplace.

Table 3 Gender / Victim of mobbing

\begin{tabular}{|c|c|c|c|c|c|c|c|c|c|c|}
\hline \multicolumn{11}{|c|}{ Pivot table Gender / Victim of mobbing } \\
\hline Gender & \multicolumn{3}{|c|}{$\begin{array}{c}\text { Victim of mobbing } \\
\text { YES }\end{array}$} & \multicolumn{4}{|c|}{$\begin{array}{c}\text { Victim of mobbing } \\
\text { NO }\end{array}$} & \multicolumn{3}{|c|}{ Total lines } \\
\hline Man & \multicolumn{3}{|c|}{37} & \multicolumn{4}{|c|}{27} & \multicolumn{3}{|c|}{64} \\
\hline Woman & \multicolumn{3}{|c|}{36} & \multicolumn{4}{|c|}{56} & \multicolumn{3}{|c|}{92} \\
\hline Sum & \multicolumn{3}{|c|}{73} & \multicolumn{4}{|c|}{83} & \multicolumn{3}{|c|}{156} \\
\hline & \multicolumn{10}{|c|}{$\begin{array}{l}\mathrm{t} \text { tests, grouped: Gender } \\
\text { Group 1: man } \\
\text { Group 2: woman }\end{array}$} \\
\hline Variable & $\mathrm{t}$ & SV & & & $\begin{array}{c}\mathrm{N} \\
\text { men }\end{array}$ & $\begin{array}{c}\mathrm{N} \\
\text { women }\end{array}$ & & $\begin{array}{l}\text { andard } \\
\text { viation } \\
\text { men }\end{array}$ & $\begin{array}{c}\text { standard } \\
\text { deviation } \\
\text { women } \\
\end{array}$ & $\begin{array}{c}\mathrm{F} \\
\text { ratio }\end{array}$ \\
\hline $\begin{array}{l}\text { Victim of } \\
\text { mobbing }\end{array}$ & $\begin{array}{c}- \\
1.98628 \\
\end{array}$ & 154 & 0.04 & & 64 & 92 & & 50000 & 0.493023 & 1.028501 \\
\hline
\end{tabular}

To test this hypothesis was used Student t-test at a significance level of 0.05 . The pvalue is 0.048777 , which is less than the determined level of significance. This fact proves the statistical difference between the occurrence of mobbing and gender. As in our sample of respondents, men were more often the victims of mobbing, we confirm the hypothesis $\mathrm{H}_{3}$.

In testing the last two hypotheses $\left(\mathbf{H}_{4}\right.$ : We assume that younger employees are more likely to be victims of mobbing than older employees; Hs: We assume that employees with 
lower education are more likely to be victims of mobbing than employees with higher education), we used one-factor analysis of variance at a significance level of 0.05 . The statistical dependence was also confirmed in this case ( $p$-value $=0.000253<0.05$ ). Young people are more likely to be victims of mobbing than their older colleagues. We confirm hypothesis $\mathbf{H}_{4}$.

The last hypothesis of statistical dependence between education of employees and occurrence of mobbing in the workplace was also confirmed. The $p$-value $=0.00361<0.05$ pointed out strong statistical dependence. The lowest occurrence of mobbing was confirmed with employees who have obtained the bachelor's degree, while the highest occurrence was in case of employees with full secondary education (i.e. with final certificate). It can be stated that the occurence of mobbing is lower in case of employees with higher education. We confirmed hypothesis $\mathbf{H}_{5}$.

\section{Conclusion}

All forms of violence in the workplace, including bullying and mobbing, have a highly negative impact on physical and mental health and relationships of employees, as well as on the overall working atmosphere. Our research confirmed that despite mobbing being a relatively common phenomenon, the circumstances in the Slovak Republic do not create sufficient conditions that would enable fighting against its occurrence. For this reason, violence in the workplace is viewed and referred to as an unsolved phenomenon, which often results in its intentional overlooking, while bullying employees and/or witnesses of mobbing are silent about the occurring problem, mostly for the fear of losing their job. In the fight against mobbing and other forms of similar violence, we consider it necessary to initiate all helpful components and parties and involve them in the solution, which require prevention by the employer, e.g. providing sufficient information and assistance from the state and non-state components, as well as adopting proper legislation [18]. An important role in applying appropriate measures in case bullying occurs, should be played not only by the state and other relevant state authorities, but also non-governmental organizations and civic associations whose activities focus on this issue. Elimination of mobbing is conditioned by proper selection of managerial practices, e.g. supporting continuous education and development of employees, supporting and enhancing communication at all levels of the enterprise, sharing information and knowledge, communicating and discussing issues clearly and with respect, listening to employees' problems in case they occur, and providing training for both hard and soft skills $[19,20]$. All mentioned attempts to eliminate the signs of mobbing in a workplace lead to building trust and creating of culture of quality in an enterprise.

\section{References}

1. D. Benčiková, D. Malá, M. Minárová, How culturally intelligent are Slovak small and medium business? 7th International Days of Statistics and Economics, 109-121, (2013)

2. S. Lorincová, M. Hitka, Z. Balazová, Corporate culture in Slovak enterprises as a factor of HRM quality - case study. International Journal for Quality Research 10, 4 (2016)

3. J. B. Avey, T. S. Wernsing, F. Luthans, Can positive employees help positive organizational change? Impact of psychological capital and emotions on relevant attitudes and behaviors. Journal of. Apply Behavioral Science 44 (2018)

4. G. K. Kanji, H. Yui, Total quality culture. Total Quality Management 8, 6 (1997). 
5. S. A. Dellana, R. D. Hauser, Toward defining the quality culture. Engineering Management Journal 11, 2 (2015)

6. C. Gaganic, F. Pasiouras, F. Voulgari, Culture, business environment and SMEs' profitability: Evidence from European countries. Economic Modelling, 78 (2019)

7. E. H. Schein, Corporate Culture - Survival Guide (Audible Studios on Brilliance Audio, Grand Heaven, 2016)

8. R. Lukášová, I. Nový, Organizační kultura: od sdílených hodnot a cílů $k$ vyšší výkonnosti podniku. (Grada, Praha, 2004)

9. M. Vargová, Psychický terror na pracovisku - mobbing. Psychológia práce 2, 9-14, (2003)

10. F. Bulutlar, E. U. Oz, The effects of ethical climates on bullying behaviours in the workplace. Journal of Business Ethics 86, 3 (2009)

11. H. Leymann, A. Gustafsson, Mobbing at work and the development of post-traumatic stress disorders. European Journal of Work and Organizational Psychology 5, 2 (1996)

12. E. Morovicsová, Komunikácia v medicine (Univerzita Komenského, Bratislava, 2014)

13. W. Vandekerckhove, M. S. R. Commers, Dawnward workplace mobbing: A sign of the times? Journal of Business Ethics 45, 1-2 (2003)

14. P. Zukauskas, J. Vveinhardt, Mobbing diagnosis instrument: Stages of construction, structure and connectedness of criteria. Journal of business economics and management 12, 2 (2011)

15. L. Svobodová, Vybrané statě o kvalitě pracovního života (Vysoká škola ekonomická, Praha, 2008)

16. K. J. Hurt, J. Welbourne, Conflict and decision-making: Attributional and emotional influences. Negotiation and Conflict Management Research 11, 3 (2018)

17. M. Venglařová, Sestry v nouzi - Syndrom vyhoření, mobbing, bossing (Grada publishing, Praha, 2011)

18. E. Baillien, I. Neyens, H. De Witte, International Small Business Journal Researching Entrepreneurship, 29, 6, 610-625, (2011)

19. N. Bouranta, E. Psomas, M. F. Suarez-Barraza, The key factors of total quality management in the service sector: a cross-cultural study. Benchmarking-an International Journal 26, 3 (2019)

20. A. Cassar, G. d'Adda, P. Grosjean, Institutional quality, culture, and norms of cooperation: Evidence from behavioural field experiments. Journal of Law and Economics 57, 3 (2014) 